$\S=-$

\title{
Analysis of Language Skills Competencies through the Intrinsic Elements of the Short Story with the Learning Motivation and Discovery Learning
}

\author{
Yetty Morelent $^{* 1}$, Hendra Hidayat ${ }^{2}$, Susi Herawati ${ }^{3}$ Marsis $^{4}$, Riche Karnilla ${ }^{5}$ \\ Corresponding author E-mail: morelent104@yahoo.com
}

\begin{abstract}
The purpose of this study is to analyze language skills competencies using the intrinsic element of the short stories and its impact on students' learning motivation using discovery learning method in senior high school. The research was Quasi-Experiment with a $2 \times 2$ factorial design. Data collection was conducted through two instruments items; non-test (questionnaire) for the learning motivation and test (essay) for the ability to identify intrinsic elements of short stories. The results of the research indicated that firstly, the ability to identify intrinsic elements of short stories of the students who were taught by using discovery learning method is better than students ability who were taughtconventionally. Secondly, it means that the ability to identify the intrinsic elements of short stories of the highly motivated students who were taught by using discovery learning method was higher than highly motivated students who are taught by using conventional method.. Thirdly, the ability to identify intrinsic elements of theshort story of students who have low learning motivation taught by using discovery learning method is higher than the students have low learning motivation taught by using conventional methods. Finally, there is no interaction between discovery learning method and learning motivation on the ability to identify the intrinsic elements of the short stories.From the result, it can be concluded that discovery learning methods can be used in learning ability to identify the intrinsic element of short stories.
\end{abstract}

Keywords: Discovery Learning, Learning Motivation, Short Stories.

\section{Introduction}

Language skills are one of the important elements that determine a person's success in communication. According to Tarigan (1), language skills include four aspects: listening, speaking, reading, and writing. In Indonesia, students do not show adequate masteryof the language skills. Moreover, Amiranti (2) sourced data from the United Nations Educational, Scientific, and Cultural Organization (UNESCO) andshowed the percentage of children's reading interest in Indonesia is only 0.01 percent, i.e. from 10,000 Indonesian children, only one person who likes to read. In addition, the Office of the National Library of Indonesia noted that 90 percent of people aged over 10 years like to watch television, but do not like to read books. Compared with developed countries, such as Australia or Singaporereading interest of Indonesian people is low. In developed countries, each people read 20 to 30 books a year. By contrast, in Indonesia, most people aged between $0-10$ years old only read three books (3). Furthermore, Firdaus (3) stated that the problem of language skills is caused certainly by a lot of factors, such as culture and reading interest, memorizing oriented curriculum (not understanding the books), difficulties in accessing the books, a lack of desire to read books of literature, lack of motivation to learn, and learning methods which are less keeping the students interested and learning actively.

This problem occurs in schools in Indonesia as the information gathered through observation conducted by researchers in high schools. It is evident that students are less excited and less motivated to learn Bahasa Indonesia, especially in learning listening skills for understanding literary of short stories. Lack of listening skills and understanding the literary material can be seen from students' lack of ability to identify the intrinsic elements that build the short story. Lack of listening skill happens because strategies and instructional methods used by teachers are not effecitive and interesting so that many students are lazy to read and unmotivated. Lack of motivation has an impact on the number of students who did not pass the Indonesian subjects. Teachers still predominantly useconventional teaching methods, such as lecturing. In other words, learning activities are still centred on the teacher. Teachers still have trouble using varied teaching methods and as a results students do not actively involved in learning activities.It is important for teachers to be skillfull in using strategies and methods in teaching in order to motivate students to learn and to do needs analysis previously (4).

One of the methods considered relevant in studying aspects of listening skills is throughdiscovery /invention method. Discovery method is a learning model that was developed based on the views of constructivismwhich emphasizes the importance of understanding the structure or important ideas on a scientific discipline, through active involvement of students in the learning process.

Other factor that influence the learning process is motivation to learn. A well-motivated creative generation isable to produce something for the benefit of themselves and others. A study on Indonesian students' motivation by Hasan (5) revealed that teachers play a central role in the increase or the decrease of students' motivation. Therefore, teachers must be good at increasing the desire of students to learn.Especially in the activities of listening. 
Research related to language skills has been widely studied (6-10). From the previous elaboration, the researchers were interested in conducting a study on analysis of developing language skills competencies through the intrinsic elements of short stories with the motivation to learn and discovery learning in senior high school.

\section{Literature Review}

\subsection{Overview of the Discovery Learning and Learning Motivation}

Discovery learning is similar to the inquiry. The inquiry is the process of answering questions and solving problems based on facts and observations. Meanwhile, discovery is to find a concept through a series of data or information obtained through observation or experiment. The method of discovery learning is a learning method which focuses on students-centered rather than teacheroriented. Characteristics of discovery learning are students actively find ideas and get their own meaning. Learning is not submitted in its final form, but the students search for information themselves. In order to have optimum learning, the teachers are required to be creative in improving the students' motivation. To improve students' motivation, (11) reveals some clues; [1] objectives to be achievedis to be clarified; [2] students' interest has to be generated; [3] a fun atmosphere the learning process is to be created; [4] the faithful of students' success should be given a reasonable complement; [5] provide ratings; [6] the results of the students' work should be providedwith comments; [7] competition and cooperation should be created.

\subsection{Intrinsic Elements of Short story}

Intrinsic elements are elements that build the literature itself Nurgiyantoro (12) explains that the intrinsic elements of short stories consist of the theme, story, plot, characters, setting, the point of view, values and style. The following is the discussion of each of the intrinsic elements; [1] the theme is what is at issue in the literature, andthe issue in question is the main issue in a literary work; [2] the story isaspects in a literary work whicharevery essential,containsnarrative expression, and consists of the event and a manifestation of its existence; [3] a flow chart or plot is a series of events that show chronological or causal relationships which form the unity of the story; [4] peoples and personalitiesare a character who appear in a work of narrative or drama, [5] background or settingis a specific location of where the story take place,or psychological and moral condition of a state; [6] viewpointis the way or the view that is used as means for presenting characters, action, background, and events that make up the story; [7] messageis the final part where the message of the story is read and is related to how the reader understand the text or short story, and [8] language styleis the style which shows how the author conveys his ideas using language beautifullyas well as the author ability to describe the meaning and atmosphere which can touch the intellectual power and emotion of the reader.

\section{Methods}

\subsection{Type, Place and Time of the Research}

This research wasa quasi-experiment study by using a quantitative approach. The population of the study was 215 students. To test hypothesis 1,36 classes for each group of control and experiment were used. To test hypotesis 2 and 3, the number of classes for each group was 18.This study uses factorial design $(2 \times 2$ factorial designs to examine, the effect of the use of discovery learning methods on the ability to identify the intrinsic elements of short stories. The study was conducted at several high schools in the city of Padang, West Sumatera, Indonesia..

\subsection{Data Collection}

The data were collected using two instruments, namely questionnaires and tests. The questionnaire was used to assess the students' motivation while the test was used to measure students' ability to identify the intrinsic elements of short stories. In other words, test was utilized to obtain data on students' cognitive abilities after learning the material to identify the intrinsic elements of short stories.

\subsection{Data Analysis}

The procedures of analysizing the data were as follows. First, the students were asked to fill out the questionnaires. Second, questionnaires were check whether there were items which were not filled by the students and, if any, it was not included in the data. After that the written test results in the form of essays were checked. Fourth, the questionnaires and the test were scored. Then, the score values were changed by Rating Reference and by using the percentage formula. This percentage formula aimed to determine the level of students' ability in determining the intrinsic elements of short stories. This step was followed by converting the ability to determine the intrinsic elements and students' learning motivation using a benchmark scale (scale of 10 . Then the data were displayed in the form of a histogram.Finally, before testing the hypothesis, hypothesis study requirements were conducted. They were normality test, homogeneity test, and then continued to test the hypothesis.

\section{Results}

Testing the hypothesis was aimed to see the significance of the treatment applied to the sample. This hypothesis was tested after having the results of students' ability to identify intrinsic elements of short stories test. For hypotheses 1, 2 and 3, the formula used was t-test formulaMeanwhile,the fourth hypothesis was testedby using analysis of variance (Anova) with F-test formula.

\section{Hypothesis 1}

The results of the test for hypothesis 1 are presented in the table below:

Table 1. Hypothesis 1

\begin{tabular}{|c|c|c|c|c|c|c|c|c|}
\hline No & Sample & $\mathbf{n}$ & $\mathbf{S}_{\text {comp }}$ & $\mathbf{A}$ & dk & $t_{h}$ & $t_{t}$ & Remarks \\
\hline 1. & $\begin{array}{l}\text { Class } \\
\text { ment }\end{array}$ & 36 & \multirow[t]{2}{*}{9,30} & \multirow[t]{2}{*}{0,05} & \multirow[t]{2}{*}{72} & \multirow[t]{2}{*}{3,570} & \multirow[t]{2}{*}{1,666} & $\begin{array}{l}\mathrm{H}_{1} \text { is accept- } \\
\text { ed }\end{array}$ \\
\hline 2. & Class Controls & 36 & & & & & & \\
\hline
\end{tabular}

Table 1 showsthat the combination of both the sample variance was 9.30. For a real level with $\alpha=0.05$ and df $72, t_{\text {calculatedwas }}$ generated for 3,570, while $t_{\text {table }}$ obtained was 1,666 . It was concluded that $\mathrm{H}_{0}$ was rejected and $\mathrm{H}_{1}$ was accepted because oft $t_{\text {calculated }}>\mathrm{t}_{\text {table. }}$. It means that students' ability to identify the intrinsic elements of short stories who were taught by using discovery learning method was higher than the students who were taught by using conventional method.

\section{Hypothesis 2}

The results of the test for hypothesis 1 are presented in the table below:

Table 2. Hypothesis 2

\begin{tabular}{|l|l|c|c|c|c|c|c|c|}
\hline No & \multicolumn{1}{|c|}{ Samples } & $\mathbf{N}$ & $\mathbf{S c o m p}$ & $\mathbf{A}$ & $\mathbf{d k}$ & $\mathbf{t}_{\mathbf{h}}$ & $\mathbf{t}_{\mathbf{t}}$ & Remarks \\
\hline 1. & $\begin{array}{l}\text { Class Experi- } \\
\text { ment }\end{array}$ & 18 & \multirow{2}{*}{4,71} & 0,05 & 36 & 4,525 & 1,690 & $\begin{array}{c}\mathrm{H}_{1} \text { is } \\
\text { accepted }\end{array}$ \\
\cline { 1 - 3 } & Class Control & 18 & & & & \\
\hline
\end{tabular}

Table 2 shows that the combination of both samples variance was 4.71. For a real level with $\alpha=0.05$ and $\mathrm{df} 72, \mathrm{t}_{\text {calculatedwas }}$ generated for 4,525 , while $\mathrm{t}_{\text {table }}$ obtained was 1,690 . It was concluded that $\mathrm{H}_{0}$ 
isrejected and $\mathrm{H}_{1}$ was accepted because oft $\mathrm{calculated}>\mathrm{t}_{\text {table }}$.It means that the ability to identify the intrinsic elements of short stories of the highly motivated students who were taught by using discovery learning method was higher than highly motivated students who are taught by using conventional method.

\section{Hypothesis 3}

The results of the test for hypothesis 3 are presented in the table below:

Table 3. Hypothesis 3

\begin{tabular}{|c|c|c|c|c|c|c|c|c|}
\hline $\begin{array}{c}\text { No } \\
\text {. }\end{array}$ & Samples & $\mathbf{N}$ & $\begin{array}{c}\text { Scom } \\
\mathbf{p} \\
\end{array}$ & $\mathbf{A}$ & $\begin{array}{l}\mathbf{D} \\
\mathbf{k}\end{array}$ & $t_{h}$ & $t_{t}$ & $\begin{array}{c}\text { Descrip- } \\
\text { tion }\end{array}$ \\
\hline 1 & $\begin{array}{l}\text { Class } \\
\text { Experi- } \\
\text { ment }\end{array}$ & $\begin{array}{l}3.12 \\
0\end{array}$ & \multirow[t]{2}{*}{4.75} & \multirow{2}{*}{$\begin{array}{c}0.0 \\
5\end{array}$} & \multirow[t]{2}{*}{36} & \multirow{2}{*}{$\begin{array}{l}1 \\
8\end{array}$} & \multirow{2}{*}{$\begin{array}{c}4.48 \\
7\end{array}$} & $\begin{array}{c}\mathrm{H}_{1} \text { is } \\
\text { accepted }\end{array}$ \\
\hline 2 & $\begin{array}{l}\text { Class } \\
\text { Controls }\end{array}$ & 18 & & & & & & \\
\hline
\end{tabular}

Table 3 shows that the combination of both the sample variance is 4.75. For a real level with $\alpha=0.05$ and $\mathrm{df} 36, \mathrm{t}_{\text {calculated }}$ was generated for 4.487, whereas $t_{\text {table }}$ obtained was 1,690. It can be concluded that $\mathrm{H}_{0}$ was rejected and $\mathrm{H}_{1}$ was accepted because oft $t_{\text {calculated }}>\mathrm{t}_{\text {table }}$. It means that the ability to identify the intrinsic elements of short stories of the low motivated students who were taught by using discovery learning method was higher than low motivated students who are taught by using conventional method.

\section{Hypothesis 4}

Hypothesis 4 was tested by using two-way ANOVA test with $f$ test . The results are presented in table 4 .

Table 4. Hypothesis 4

\begin{tabular}{|l|l|r|r|r|c|c|}
\hline No. & $\begin{array}{l}\text { Diversity } \\
\text { Source }\end{array}$ & $\begin{array}{c}\text { Sum of } \\
\text { Squares }\end{array}$ & $\begin{array}{l}\text { Degrees } \\
\text { Free }\end{array}$ & $\begin{array}{c}\text { Central } \\
\text { Square }\end{array}$ & $\mathbf{F}_{\mathbf{h}}$ & $\mathbf{F}_{\mathbf{t}}$ \\
\hline 1. & A & 3358,76 & 1 & 3358,76 & 0,275 & 3,940 \\
2. & B & 112,35 & 1 & 1112,35 & 0,091 & 3,940 \\
3. & AB & 827668,70 & 1 & 827668,70 & 0,679 & 3,940 \\
4. & Error & 211238,50 & 68 & 12171,50 & & \\
\hline & Total & $\mathbf{7 1 6 6 , 8 8}$ & $\mathbf{7 2}$ & $\mathbf{1 2 1 7 1 , 5 0}$ & & \\
\hline
\end{tabular}

Based on the Table 4 , it can be described that $\mathrm{F}_{\text {calculated }}$ for the interaction is 0.679 , while the $\mathrm{F}_{\text {table }}$ with $\alpha=0.05$ is $\mathrm{F}_{0.05}(1 ; 72)=$ 3.940. It was concluded that $\mathrm{H}_{0}$ is accepted and $\mathrm{H}_{1}$ is rejected because of $F_{\text {calculated }}<\mathrm{F}_{\text {table. }}$. It means there is no interaction between discovery learning methods with learning motivation in influencing the ability to identify the intrinsic elements of short stories

\section{Discussion}

\section{Effect of discovery learning method towards the ability to identify Intrinsic Elements of short stories}

Before the ability test of identifying the intrinsic elements of short stories was conducted, the skill level between the experimental class and the control class in identifying the intrinsic elements of short stories were believed to be different. This assumption was stated as the difference in treatment applied to these two classes in learning to identify the intrinsic elements of short stories. During the learning process, experimental class students experience different learning atmosphere compared to thecontrol class. It refers to the opinion of (13) who says that the discovery learning method in learning to identify the intrinsic elements of short stories aims to improve the learning process to become more meaningful. This discovery learning method assigns responsibility for the students to learnbythemselves. The teacher does not act and explain the material directly but becoming one source of learning for students (14). By using discovery learning models, students are better able to develop and apply the knowledge they have gained and use the potential of learning resources around them. This is due to the fact that in the learning process, the students are expected to be more critical and creative, so they do not only received materials from the teachers but also able to look for other sources. Thus, students find the principles and concepts of the learning process itself.

\section{The ability to identify intrinsic elements of short stories of highly motivated students who were taught by using Discovery Learning Method and Conventional Methods}

Results of the second hypothesistesting showedthat the ability to identify the intrinsic elements of short stories of highly motivated students who were taught by using Discovery Learning Methodwas better than thehighly motivated students who were taught by using conventional methods. The differencebetween the two classes with high learning motivation level was indicated by the average value of the ability test to identify the intrinsic elements of different short stories. Overall students with high learning motivation in the experimental class acquired the ability to identify elements of the intrinsic value of short stories above the standard value. This was caused by the influence of the treatment applied to the experimental class. The results was in contrast with the control classes, which only used conventional learning. In contrast, no one in the control class, showed the ability to identify the intrinsic elements of short stories above the standard value and no one under the standard value.

The ability to identify intrinsic elements of short stories of low motivated students who were Taughtby Using Discovery learning method and Conventional Methods

Results of testing the third hypothesissuggest that the ability to identify the intrinsic elements of short stories by low motivated students whowere taught by using Discovery learning method was better than low motivated students who were taught by using conventionalmethod. Similar to the second hypothesis, which tested the highly motivated students, the difference in the ability to identify the intrinsic elements of short stories in both classes was also shown by the difference in the average of tests score.In general, the ability to identify the intrinsic elements of short stories of low motivated students in both classes of experiment class and control class is under the determined standard value. However, although both classes had a low learning motivation, the ability test scores of identifying the intrinsic elements of the short storiesfor experimental group remained higher than the control group.It was also caused by the effect of treatment of discovery learning methods set forth in the experimental class. In accordance with what was previously described, although low motivatited students in the experimental class had higher intrinsic value of the ability to identify elements of short stories than the control class, increasing motivation to learn inbothclasses need to be done. It is required a relatively long timefor well-motivated students to learn efficiently. Besides the time factor, students willingness to learn was very important.

\section{Interaction of Discovery learning method with learning motivationin affectingthe ability to identify Intrinsic Elements of short stories}

Based on the ANOVA to test the fourth hypothesis, it can be seen that there is no interaction between the discoveries learning method with learning motivation towards the ability to identify the intrinsic elements of short stories.. However, the motivation is not the only factor that determines the success of students' ability to identify the intrinsic elements of short stories. There are many other factors, such as customs, intelligence, ability, talent, readiness, and others (15). In addition, teacher readiness factor in discovery learning methods plays an important role in the learning process so that learners can identify the intrinsic elements of short stories which will affect the ability to listen to short stories.

The absence of interaction means thatwhen discovery learning method was used, there was no difference in the ability to identify 
the intrinsic elements of the short stories, between students who have high learning motivation and students who have low learning motivation. The same was true when the conventional method was used. This means that each factor of discovery learning methods and learning motivation do not depend on each other in affecting learners ability to identify the intrinsic elements of short stories (16). There was no interaction was partly because students have not learned using discovery method previously. Nevertheless, discovery learning methods look more effectively applied to students with both types of motivation. Motivated. (17-20). In other words, discovery learning methods can be used to teach students who have high motivation as well as students with low motivation. Furthermore, the use of discovery learning methods may improve the students' ability to identify intrinsic elements in short stories better than the conventional method (21), and the use of learning methods which is implemented must correspond to language learning (22-24). The application of discovery learning methods on the subjects of Indonesian language to identify the intrinsic elements of short stories is one of the alternatives to improve students' listening skills. The discovery learning method is a lesson that can engage students actively in learning. This condition is strongly in line with the selection of strategies and learning methods in language learning (25-27). Learning associated with real life and the environment close to the students allows students to develop ideas in listening to short stories text. In this activity, the involvement of teachers is as facilitators. Teachers encourage students to develop their potential optimally. Thus, the discovery learning method can be used as a learning method that is appropriate and able to improve students' learning outcomes (28).

\section{Conclusion and Recommendation}

After the elaboration of research results and its discussion, it can be concluded that, first, the ability to identify intrinsic elements of short stories of the students who were taught by using discovery learning method is better than students ability who were taught conventionally. Second, highly motivated students who were taught by using discovery learning method is higher than highly motivated students who were taught by using conventional methods. Third, the ability to identify intrinsic elements of short story of students who have low learning motivation taught by using discovery learning method is higher than the students have low learning motivation taught by using conventional methods. Fourth, there is no interaction between discovery learning methods and learning motivation on the ability to identify the intrinsic elements of the short stories.

This research is only focused on the effect of using discovery learning methods on students' language skills through the use of intrinsic elements of short stories. It is recommended for further research examine how discovery learning affect students' achievement using other materials in different types of writing such as academic paper or article.

\section{Conflict of Interest}

The author declares no conflict of interest.

\section{Acknowledgments}

This research was funded by research of Bung Hatta University No. 1041 / SK-2 / KP / I-2018.

\section{References}

[1] Tarigan, Hendry Guntur. (2008). Listening as a Language Skill. Bandung: Angkasa, Ind

[2] Amiranti, C.C. (2017). Low Reading Interest, Need New Breakthrough?.online. http://edukasi.kompas.com/read/2017/06/22/17223781/minat.baca.anak. rendah.perlu.terobosan. baru.

[3] Firdaus, F. (2015). Cause 90 percent of Indonesian people do not like to read. online. https://www.rappler.com/indonesia/111832-masyarakatindonesia-tak-suka-membaca

[4] Ganefri.,Hidayat, H., Kusumaningrum, I., \&Mardin, A. (2017). Needs Analysis of Entrepreneurship Pedagogy of Technology and Vocational Education with Production Based Learning Approach in Higher Education. International Journal of Advanced Science, Engineering and In$\begin{array}{llll}\text { formation } & \text { Technology } & \text { 7: } & \text { 1701-1707. }\end{array}$ http://dx.doi.org/10.18517/ijaseit.7.5.1510

[5] Hasan, Diana Chitra (2018). What Factors Influence Changes in Students' Motivation to Learn English as a Foreign Language? Asian EFL Journal. 20 (2). 20 -32

[6] Morelent, Y. (2013). SMS Language from Graphological, Syntactic, and Psycholinguistic Sections as well as Its Implication to Indonesian Language Learning. Jurnal Al-Ta'lim, 1, 472-479.

[7] Morelent, Y. (2015). Character Building and Language Capabilities of Children Through Storytelling. Prosiding KOLITA 13, KonferensiLinguistikTahunanAtmajayake- 13 Tingkat Internasional, Atmajaya Jakarta 8-9 April 2015

[8] Morelent, Y. (2017). Influence of Academic Supervision and Motivation To Teacher Performance. International 2nd Conference On Educational Studies 21 st Century Educational Initiatives. Le Grandeur Palm Resort, Johor 10 - 11 Oktober 2017

[9] Mursalim, M. (2017). Cultural Literacy Growth With Application of Language Skills Sciences (Reading and Writing). Journal of Culture, Arts, Literature, and Linguistics,3, 31-38.

[10] Afifi, F., Sabdaningtyas, L., \&Akhyar, F. (2017). Influence of Role Playing Model on Student Speaking Skills in Integrated Learning. JurnalPedagogi, 6.

[11] Sanjaya, Wina. 2008. Curriculum and Learning. Jakarta: Kencana, Ind.

[12] Nurgiyantoro, Burhan. (2001). Assessment of Competence Based Language Learning. Yogyakarta: BPFE, Ind.

[13] Suprijono, Agus. (2012). Cooperative Learning and Paikem Applications. Yogyakarta: PustakaPelajar, Ind.

[14] Hamalik, Oemar. (2011). Teaching and learning process. Jakarta: BumiAksara, Ind.

[15] Arinawati, Eni., Slamet, St.Y., Chumdari. (2014). Pengaruh Model Pembelajaran Discovery Learning TerhadapHasilbelajarMatematikaDitinjau Dari Motivasibelajar. JurnalDidaktikaDwijaIndria, 2, 1-8

[16] Pardede, P. (2011). Using short stories to teach language skills. Journal of English Teaching, 1, 14-27.

[17] Wen, X., (2011). Chinese language learning motivation: A comparative study of heritage and non-heritage learners. Heritage Language Journal, 8, 41-66.

[18] Yang, Y.T.C. and Wu, W.C.I. (2012). Digital storytelling for enhancing student academic achievement, critical thinking, and learning motivation: A year-long experimental study. Computers \& education, 59, 339tion:

[19] Busse, V. and Walter, C. (2013). Foreign language learning motivation in higher education: A longitudinal study of motivational changes and their causes. The Modern Language Journal, 97, 435-456.

[20] Teeter, J.L. (2017). Improving Motivation to Learn English in Japan with a Self-Study Shadowing Application. Languages, 2, 19. doi:10.3390/languages2040019

[21] Hidayat, H. (2017). Impact of Learning with the Production-Based Learning Model in Vocational School. International Journal of Research in Engineering and Social Sciences, 7, 1-6. http://indusedu.org/pdfs/IJRESS/IJRESS_1057_92032.pdf

[22] Tsai, Y.L. and Shang, H.F. (2010). The impact of content-based language instruction on EFL students' reading performance. Asian Social Science, 6, 77.

[23] Alptekin, C. and Tatar, S. (2011). Research on foreign language teaching and learning in Turkey (2005-2009). Language Teaching, 44, 328353.

[24] Tomlinson, B., (2012). Materials development for language learning and teaching. Language teaching, 45, 143-179.

[25] Wong, L.L. and Nunan, D. (2011). The learning styles and strategies of effective language learners. System, 39, 144-163.

[26] Griffiths, C. (2013). The strategy factor in successful language learning. Multilingual Matters.

[27] Cohen, A.D. (2014). Strategies in learning and using a second language Routledge.

[28] Kusumaningrum, I., Hidayat, H., Ganefri, Anori, S. \& Dewy, MS (2016). Learning Outcomes in Vocational Education: a Business Plan Development by Production-Based Learning Model Approach. International Journal of Environmental and Science Education, 11, 1191711930. 